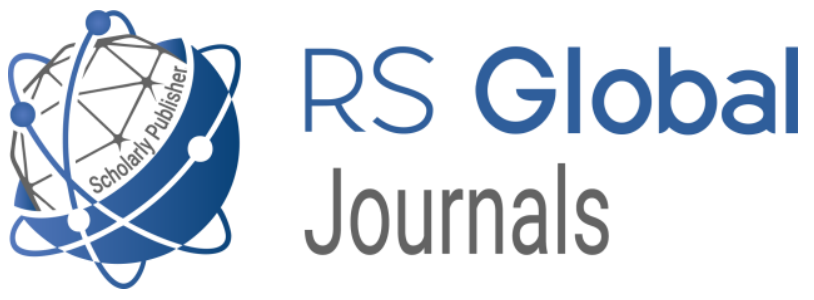

Scholarly Publisher

RS Global Sp. z O.O.

ISNI: 0000000484952390

Dolna 17, Warsaw, Poland 00-773

Tel: +48226022703

Email: editorial_office@rsglobal.pl

JOURNAL International Journal of Innovative Technologies in Social Science

p-ISSN

$2544-9338$

e-ISSN

2544-9435

PUBLISHER

RS Global Sp. z O.O., Poland

ARTICLE TITLE

FORMATION OF SOCIAL AND PSYCHOLOGICAL

ARTICLE TITLE

ADAPTATION OF MIGRANT CHILDREN IN THE CONTEXT OF EDUCATIONAL SYSTEM

$\operatorname{AUTHOR}(\mathbf{S})$

Khachaturyan Yu. R.

Khachaturyan Yu. R. (2020) Formation of social and psychological adaptation of migrant children in the context of

ARTICLE INFO educational system. International Journal of Innovative Technologies in Social Science. 6(27). doi:

10.31435/rsglobal_ijitss/30092020/7174

DOI

https://doi.org/10.31435/rsglobal_ijitss/30092020/7174

RECEIVED

28 July 2020

ACCEPTED

23 August 2020

PUBLISHED

27 August 2020

LICENSE

This work is licensed under a Creative Commons Attribution

4.0 International License.

(C) The author(s) 2020. This publication is an open access article. 


\title{
FORMATION OF SOCIAL AND PSYCHOLOGICAL ADAPTATION OF MIGRANT CHILDREN IN THE CONTEXT OF EDUCATIONAL SYSTEM
}

\author{
Khachaturyan Yu. R., \\ Researcher of scientific degree, Social Psychology Department, \\ Taras Shevchenko National University of Kyiv \\ ORCID: https://orcid.org/0000-0002-1267-661X
}

DOI: https://doi.org/10.31435/rsglobal_ijitss/30092020/7174

\section{ARTICLE INFO \\ Received 28 July 2020 \\ Accepted 23 August 2020 \\ Published 27 August 2020}

\section{KEYWORDS}

social and psychological adaptation, anxiety, selfperception, migrant children, art therapy.

\begin{abstract}
The article describes the results of the implementation of the program of social and psychological adaptation of migrant children from the war zone and the temporarily occupied districts of Donetsk and Luhansk regions. The results of the observational phase of the study indicate that migrant children have high rates of aggression, irritability, negativity, resentment and suspicion. Many migrant children are ignored by their classmates and have the status of isolated, which indicates a low level of their adaptation to the new educational environment. The molding experiment was conducted in an educational institution. The comprehensive program is designed to take into account the age of migrant children: primary school students and students of middle and senior classes. The description of the developed program of social and psychological adaptation which contains exercises and training employments is provided. The results of the formative experiment showed a positive dynamics of socio-psychological adaptation of migrant children, which indicates the effectiveness and feasibility of a comprehensive program, which was used in secondary school. The program included a variety of classes and exercises, such as reducing anxiety, increasing self-esteem, relieving fears, developing communication skills. In addition, the joint work of migrant children in the group helped to unite children of different nationalities, cultures, and encouraged mutual respect and tolerance.
\end{abstract}

Citation: Khachaturyan Yu. R. (2020) Formation of social and psychological adaptation of migrant children in the context of educational system. International Journal of Innovative Technologies in Social Science. 6(27). doi: 10.31435/rsglobal_ijitss/30092020/7174

Copyright: (C) 2020 Khachaturyan Yu. R. This is an open-access article distributed under the terms of the Creative Commons Attribution License (CC BY). The use, distribution or reproduction in other forums is permitted, provided the original author(s) or licensor are credited and that the original publication in this journal is cited, in accordance with accepted academic practice. No use, distribution or reproduction is permitted which does not comply with these terms.

Problem definition. With the outbreak of hostilities in eastern Ukraine, the annexation of Crimea and parts of the Luhansk and Donetsk regions, a significant part of the population of these territories was forced to move to peaceful regions. Such migration processes have created economic, financial and social problems for the adult population. Childen who had to leave the territory of permanent residence with established learning traditions and social environment together with their parents and adapt to new, not always comfortable and equivalent living and learning conditions were especially acutely worried about the forced change of place of residence. This raised the problem of social and psychological adaptation of migrant children to the new educational environment with particular urgency.

The aim of research - development and verification of the effectiveness of a comprehensive program for the formation of socio-psychological adaptation of migrant children.

Research analysis. The analysis of domestic scientific literature has shown that in modern science the issue of adaptation of migrant children in the educational environment is sufficiently 
studied and ways of creating favorable conditions for the self-realization of this category of children are considered (Aleksieienko, 2005; Humennykova, 2011; Bekh, 2015; Piekhota, 2006).

The study of the problem of socio-psychological adaptation of migrant children has been widespread since the 90s of the last century. In national science the study of the adaptation process of migrant children was carried out by: K. A. Koviazina (2013), K. V. Borychenko (2015)(the problem of legal and social protection of children, including migrant children), N.C. Hevchuk (2011) (the problem of adaptation of children of labor migrants, the issues of their adaptation in the educational environment, the use of innovative technologies by psychologists and social educators in working with children), I. V. Tarasiuk (2013) was studying the problem of language adaptation of migrant children in a new socio-cultural environment.

National scientists have developed methods and tools for working with migrant children. V. M. Pihida (2012) studied the essence of such forms and methods as: individual counseling, conversation, training and others, and also determined the specifics of their application with children of migrants in educational institutions. I. M. Trubavina (2015) shows the need for social and psychological work to be conducted not only with migrant children, but also with their parents and other participants of the educational process. C. D. Bulavenko (2012) sees an educational institution as a small model of society. The researcher comes to the conclusion that it is necessary to create comfortable conditions for the adaptation of migrant children using available methods and methods of socio-psychological influence.

Main material. During the ascertaining stage of the study the features of the sociopsychological adaptation of migrant children were clarified. It was found that migrant children have high rates of physical, indirect and verbal aggression, irritation and negativism; resentment and suspicion remains above average level. Boys have significantly higher rates of physical, verbal, and indirect aggression, suspicion, resentment, hostility, and aggressiveness. More than half of migrant children take an active position in the group and are defined by group members as desirable, while the rest of the children take a passive role and are ignored members of the group, which indicates a low level of their adaptation to the new educational environment.

All indicators of socio-psychological adaptation in migrant children are within the normal range beyond the average values. It was found that the level of adaptability and self-acceptance is higher in girls compared to boys; boys have more pronounced indicators of rejection of others and escapism. With an increase in adaptability in migrant children, self-acceptance and acceptance of others increase, the level of emotional discomfort decreases, the level of internal control increases and the level of external control decreases, the level of subordination and escapism decreases.

To achieve the goal of the study, a program of socio-psychological adaptation of migrant children to the new educational environment was created and its effectiveness was tested.

The study involved 80 students, of which 51 migrant children - displaced from the war zone of Donetsk and Lugansk regions, made up the experimental group, the control group included 29 children. The control and experimental groups were formed according to the following principle: the control group included children of the local population, the experimental group - migrant children. Subsequently, the experimental group was divided into two different age groups. In addition, parents of migrant children (51 people, mothers) and 38 people - parents of children took part in the study.

To study the socio-psychological adaptation of migrant children, the following research methods were used: level of personal and reactive (situational) anxiety by Spielberger - Khanin method; Spielberger's State-Trait Anxiety Inventory; self-assessment method by S. Budassi, BussDurkee hostility inventory, Color sociometry, Rosenzweig Picture Frustration Test.

The molding experiment took place during the 2018-2019 academic year. During this time, a comprehensive program of social and psychological adaptation of migrant children was implemented in the experimental group. One of the tasks of the molding experiment was the development of a comprehensive program for the socio-psychological adaptation of migrant children in a general education institution. This program was not implemented in the control group. Re-diagnosis was carried out in order to establish the effectiveness of the program and to identify the level of formation of socio-psychological adaptation. To assess the reliability of differences when comparing the studied indicators with each other, the Student's t-test was used, which made it possible to assess the significance of differences in the means before and after the implementation of the program of sociopsychological adaptation, obtained in two samples. 
Work with migrant children was carried out according to two separate programs due to the difference in the age of migrant children. Each program had its own specific features, different types and methods of work. The first version of the program is designed for children of primary school age, the second - for children of middle and senior classes. The need to divide migrant children into different age groups was found when analyzing the results obtained during the ascertaining stage of studying the socio-psychological adaptation of migrant children. (Elkonin, 1971; Semenyuk, 1996)

The program of socio-psychological adaptation of migrant children of primary school age provided seven topics that contained various kinds of exercises.

The first lesson was aimed at getting to know all the members of the group, establishing trusting relationships, team cohesion and developing communication skills. The method of fairy tale therapy was used, containing elements of describing the individual characteristics of each member of the group with an approach to the problem of adaptation of migrant children and the mobilization of their capabilities and resources.

The second lesson was aimed at expanding children's ideas about emotions, finding acceptable ways to respond and release the accumulated negative energy without harming others. The work with children was carried out in several stages. First the children listened to a fairy tale which reveals the problem of children's aggressiveness. After that the group discussed the main problems that were revealed in the fairy tale and the possibilities of using the knowledge gained in everyday life.

In the course of processing this topic, the following exercises were used: "Air Meditation" (Mike George), which is simple meditative exercises aimed at restoring calm breathing and preventing emotionally difficult situations.

The third and fourth lessons were aimed at harmonizing self-awareness, overcoming isolation. The goal was realized through the following exercises: "Wrong drawing"; "4 questions - 4 pictures"; "I am very good"; "Braggart Contest"; "I can!" etc.

The purpose of the fifth lesson was the formation of adequate self-esteem and the desire for recognition. The goal was realized through such exercises as: "Biography from a photo"; "Everything is in order"; and etc.

The sixth lesson was aimed at improving knowledge about the norms of behavior, about the conditions of confident behavior, the formation of skills to overcome difficulties and motivation for self-education. The lessons included the following exercises: "Norms of behavior"; "Notebook"; "Association"; and etc.

The main goal of the seventh lesson was the formation of adequate self-esteem, selfconfidence, reduction of psycho-emotional stress, the formation of attention and interest in communication partners. Children of primary school age performed the following exercises: "How are you?"; "I understand you"; and etc.

After each exercise children were to give their feedback in which the children talked about their state of health, the emotions that were caused by the exercise, the difficulty of its implementation etc.

The program for adjusting the social and psychological adaptation of migrant children of middle and high school age were seven topics in the form of seven lessons.

The first lesson was aimed at getting acquainted with their psychological traits, improving ideas about the problems of aggression and learning "harmless" ways to overcome aggression. During the lesson, children performed the following visualization exercises: "Photo" (reduction); "Photo (cartoon characters)".

The second lesson was aimed at teaching how to carry out a conversation and the ability to listen to the interlocutor. The main purpose of the lesson was achieved by performing the following exercises and games: "Learn to listen and hear many"; "Magic shop"; "I'm worried about..."; "Message" etc.

The third lesson was aimed at preventing fear and developing communication skills. The main goal was achieved through a fairy tale and the exercise of awareness and processing of their own fears.

The purpose of the fourth and fifth lessons was to raise the level of self-esteem and to develop self-confidence. The following exercises were worked out during the lesson: "Ode to yourself"; "Autopilot"; "But ..."; "Symbol of confidence"; game "Mayor", "I like my body" (Abbreviated exercises by Louise Hay); etc.

The sixth and seventh sessions were aimed at bringing the group closer, increasing the level of trust between the participants. These exact classes are important in achieving socio-psychological 
adaptation. The purpose of the lesson was achieved through the following exercises: "Climber"; "Trust"; "Blind and a guide"; "Pendulum", "The silent mirror and the talking mirror"; "What's new in him"; "Answer for another"; "My portrait through the eyes of others"; "If my friend was ... myself."

During the molding experiment we collected data, the analysis of which allows us to conclude about the effectiveness of the program of social and psychological adaptation of migrant children in the educational environment. The results are given in table. 1.

Table 1. Average values according to the Buss-Durkee hostility inventory before and after the implementation of the program in the experimental and control groups

\begin{tabular}{|c|c|c|c|c|}
\hline \multirow[t]{2}{*}{$\begin{array}{c}\text { Indicators and forms of } \\
\text { aggression }\end{array}$} & \multicolumn{2}{|c|}{$\begin{array}{c}\text { Experimental group } \\
(\mathrm{N}=51)\end{array}$} & \multicolumn{2}{|c|}{$\begin{array}{c}\text { Control group } \\
(\mathrm{N}=29)\end{array}$} \\
\hline & Before & After & Before & After \\
\hline Physical aggression & 71,69 & 31,31 ** & 30,76 & 28,24 \\
\hline Verbal aggression & 70,23 & $32,77 * *$ & 27,98 & 27,19 \\
\hline Indirect aggression & 61,40 & $41,60 * *$ & 28,00 & 30,21 \\
\hline Negativism & 60,62 & $42,38 * *$ & 28,67 & 30,33 \\
\hline Irritation & 66,73 & $36,27 * *$ & 28,83 & 30,17 \\
\hline Suspiciousness & 61,49 & $41,51 * *$ & 29,00 & 28,65 \\
\hline Insult & 66,83 & 36,17 ** & 29,50 & 30,12 \\
\hline Feelings of guilt & 66,88 & $34,12 * *$ & 27,24 & 27,00 \\
\hline Hostility & 65,50 & 37,50 ** & 28,92 & 26,56 \\
\hline Aggressiveness & 72,84 & $30,16^{* *}$ & 29,54 & 30,01 \\
\hline
\end{tabular}

Note: $* *-p \leq 0,01$

The results presented in table 1 show a decrease in all indicators and forms of aggression, namely: physical aggression $(U=271,0)$, verbal aggression $(U=345,5)$, indirect aggression $(U=795,5)$, negativism $(U=835,5)$, irritation ( $U=524,0)$, suspiciousness $(U=791,0)$, insult $(U=518,5)$, feelings of guilt $(\mathrm{U}=414,0)$, Hostility $(\mathrm{U}=586,5)$ and aggressiveness $(\mathrm{U}=212,0)$.

Analysis of the results by hostility inventory shows that group work with children which was aimed at developing the ability to overcome aggression and control anger gave a positive result. Migrant children have found and mastered new constructive forms of releasing the accumulated negative energy.

Table 2. Average indicators on the scale of reactive (situational) and personal anxiety (Spielberger, adapted by Khanin) in two groups before and after the program

\begin{tabular}{|c|c|c|c|c|}
\hline \multirow{2}{*}{ Types of anxiety } & \multicolumn{2}{|c|}{$\begin{array}{c}\text { Experimental group } \\
\text { (N=51) }\end{array}$} & \multicolumn{2}{c|}{$\begin{array}{c}\text { Control group } \\
\text { (N=29) }\end{array}$} \\
\cline { 2 - 5 } & Before & After & Before & After \\
\hline Situational anxiety & 67,27 & $35,73^{* *}$ & 31,05 & 30,27 \\
\hline Personal anxiety & 67,52 & $35,48^{* *}$ & 35,02 & 34,38 \\
\hline
\end{tabular}

Note: $* *-p \leq 0,01$

Analysis of the results of anxiety after a formative experiment in migrant children showed a decrease in the level of situational $(U=496,0 ; p \leq 0,01)$ and personal anxiety $(U=483,5 ; p \leq 0,01)$. The changes that have taken place testify to the effectiveness of the implemented program because at the ascertaining stage of the study it was the indicators of anxiety that we identified as the main conditions for maladaptation of migrant children.

The implementation of the program also results in an increase in the self-esteem of migrant children (U=425,5; $\mathrm{p} \leq 0,01)$ (Fig. 1). 


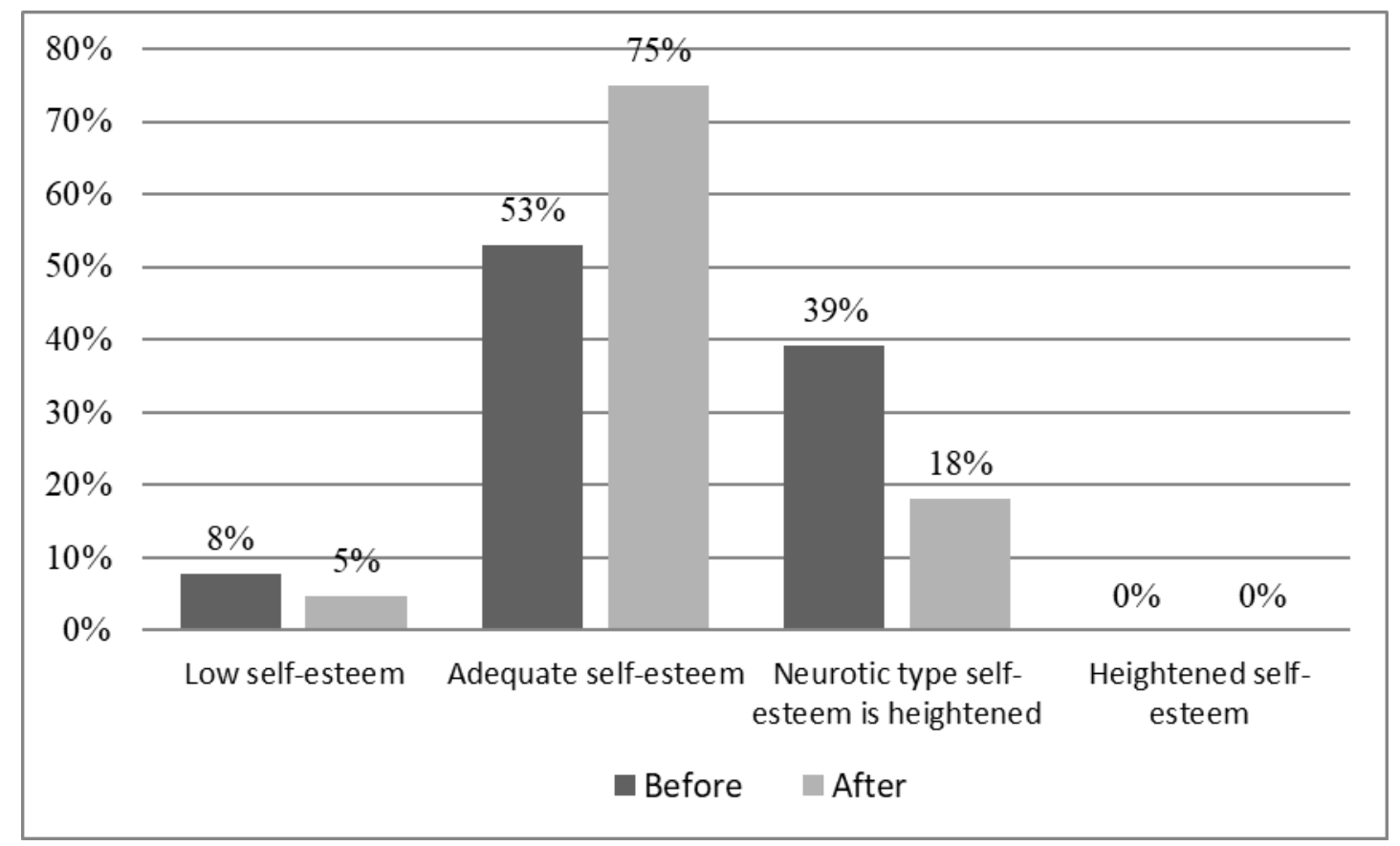

Fig. 1. The level of self-esteem of migrant children in the experimental group before and after the molding experiment $(\%)$

It was revealed that before the molding experiment an adequate level of self-esteem prevailed among the subjects (53\% of the subjects), in $39.2 \%$ - the neurotic type self-esteem was heightened, and $7.8 \%$ of the subjects had a low self-esteem. After the implementation of the program, the heightened neurotic type self-esteem decreased $(18.2 \%)$ and the percentage of migrant children with a low level of self-esteem decreased around $-4.8 \%$.

Analysis of frustration reactions before and after the formative experiment did not reveal significant changes $(\mathrm{p} \geq 0,05)$.

Before the implementation of the program, the impunitive orientation of the reaction to frustration prevailed in migrant children (in $86.3 \%$ respondents), in $11.7 \%$ of children an extrapunitive type of reaction prevailed and an intrapunitive type was revealed in $2 \%$ of the respondents. After the molding experiment, the percentage of the prevailing types of reactions remained unchanged.

Changes were revealed after the implementation of the program according to the results of the methodology for diagnosing social and psychological adaptation by K. Rogers and R. Diamond. (Table 3).

Table 3. Average values of indicators of socio-psychological adaptation of migrant children in the experimental group before and after the implementation of the program

\begin{tabular}{|l|c|c|c|c|}
\hline \multicolumn{1}{|c|}{ Scales } & Before & After & Criteria & P \\
\hline Adaptation & $\mathbf{3 1 , 6 1}$ & $\mathbf{4 2 , 2 4}$ & U=286,0 & $\mathbf{0 , 0 1 1}$ \\
\hline Self-acceptance & $\mathbf{4 0 , 2 2}$ & $\mathbf{4 5 , 4 5}$ & U=406,5 & $\mathbf{0 , 0 3 7}$ \\
\hline Acceptance of others & 21,96 & 22,90 & $\mathrm{U}=933,5$ & 0,352 \\
\hline Emotional comfort & $\mathbf{3 1 , 5 9}$ & $\mathbf{4 0 , 0 1}$ & $\mathrm{U}=\mathbf{3 9 4 , 0}$ & $\mathbf{0 , 0 3 2}$ \\
\hline Internality & 29,43 & 28,96 & $\mathrm{U}=864,0$ & 0,421 \\
\hline Desire to dominate & 45,24 & 44,03 & $\mathrm{U}=698,0$ & 0,214 \\
\hline
\end{tabular}

The data in Table 3 shows an increase in the level of adaptation of children $(U=286.0)$, which indicates the perception of others, increased the level of self-acceptance $(U=226.5)$, improved children's attitude to themselves, which is a positive moment for internal stability and self-regulation. An increase in the level of emotional comfort $(U=394.0)$ indicates an increase in the feeling of security, protection and emotional balance. 
Analysis of the results of the study in the control group did not reveal changes. Conclusively it is evident that our program has helped to improve the socio-psychological adaptation of migrant children in the educational environment.

Conclusions. During the research in order to increase the level of social and psychological adaptation of migrant children a program was developed, which was implemented in two groups of subjects: primary school children and adolescents/high school students. The program included a variety of classes and exercises, such as exercises aimed at reducing anxiety, increasing self-esteem, relieving fears and developing communication skills. In addition, the joint work of migrant children in the group helped to unite children of different nationalities and cultures, and encouraged mutual respect and tolerance.

Thus we can conclude that the program of socio-psychological adaptation has shown its effectiveness: migrant children have formed a socio-psychological adaptation to the educational environment, which will help them in later life.

Prospects for further research are to expand the scope of the developed program of sociopsychological adaptation.

\section{REFERENCES}

1. Alekseenko, T. (2005), "Socio-pedagogical support of children at risk", Social pedagogy: theory and practice, 1, 56-60 Retrieved from https://scholar.google.com.ua/scholar?hl=ru\&as_sdt=0,5\&cluster=8398643893205875459

2. Bekh, I. (2015), "Selected scientific works. Education of personality", Selected scientific work, (Volume II), Chernivtsi. Ukraine. Retrieved from https://scholar.google.com/scholar?q=related:jnYPpvoEvvsJ:scholar.google. com/\&scioq=Бех +I.+Д.+Вибрані + наукові + праці.+Виховання + особистості $++2015 \& h l=e n \& a s \_s d t=0,5$

3. Borychenko, K. (2015), "Social protection of families with children according to the legislation of Ukraine: monograph". Phoenix, Odessa. Ukraine. Retrieved from https://scholar.google.com/scholar?oi=bibs\&hl=en\&q=related:B_g75XLlADsJ:scholar.google.com/

4. Bulavenko, S. (2012), "Ways of forming a socially-adapted personality in secondary school" Bulletin of Chernihiv National Pedagogical University. Series "Pedagogical sciences", 96, 28-30. Retrieved from https://scholar.google.com/scholar?q=related:2oonaj9ChvUJ:scholar.google.com/\&scioq=Булавенко+C.+ Д.++Шляхи++формування++соціальноадаптованої++особистості++в++загальноосвітній+школі+\&hl=en\&as_sdt=0,5

5. Halperin, P. (1998), "Introduction to psychology" Psychology as an objective science: Selected psychological works. Voronezh. Russia, 94-248. Retrieved from https://scholar.google.com/scholar?q=related:EmIFVHpy1v8J:scholar.google.com/\&scioq=Гальперин+П. + Я.+Введение+в+психологию $+\& \mathrm{hl}=\mathrm{en} \& \mathrm{as} \_\mathrm{sdt}=0,5$

6. Hevchuk, N. (2011), "Organization of educational work with children of labor migrants in the conditions of a general educational institution". Kamenets-Podolsky. Ukraine, Educational and methodical manual, 128. Retrieved from https://scholar.google.com/scholar?q=related:ubVmmpqmyD0J:scholar.google.com/\&scioq $=$ Гевчук + Н. + С. ++ Організація++виховної++роботи++3++дітьми ++ трудових ++ мігрантів ++ в++уумовах +загальноосвітнього+навчального++закладу\&hl=en\&as_sdt=0,5

7. Humennikova, T. (2011), "Theoretical and methodological principles of preparation of the future teacher for personality-oriented education of junior schoolchildren in the conditions of higher education". Kiev. Ukraine, 36. Retrieved from https://scholar.google.com/scholar?hl=en\&as_sdt=0,5\&cluster=11609442607464257806

8. Zavatska, L. (2014), "Research of social needs of children of labor migrants in the new social and educational environment". Psychological and pedagogical sciences, 2, 73-76. Retrieved from https://scholar.google.com/scholar?q=related:X6tCUJlqAzoJ:scholar.google.com/\&scioq=Завацька+Л.+M. +Дослідження+соціальних +потреб+дітей +трудових +мігрантів+у+новому+соціально-

+ освітньому ++ середовищi $++\&$ hl $=$ en\&as_sdt $=0,5$

9. Kovyazina, K. (2013), "Social protection of children of labor migrants: conceptual bases and state policy". Strategic priorities, $4, \quad 50-56 . \quad$ Retrieved from https://scholar.google.com/scholar?q=related:um98CJvkRH4J:scholar.google.com/\&scioq=Ковязіна + K.+ O. + Соціальний + захист+дітей+трудових + мігрантів: + концептуальні + основи + та + державна ++ політика $+\&$ hl $=$ en\&as_sdt $=0,5$

10. Leontiev, A. (1983), "Mastering by students of scientific concepts as a problem of educational psychology". Selected psychological works. (Volume II), 324-347. Retrieved from https://scholar.google.com/scholar?q=related:mgJl_blziJUJ:scholar.google.com/\&scioq=Леонтьев+А.Н.+Овладе ние+учащимися+научными+понятиями+как+проблема + педагогической + психологии\&hl=en\&as_sdt=0,5

11. Miloslavova, I. (1974), "The concept and structure of social adaptation” Leningrad. Russia, 24. Retrieved from https://scholar.google.com/scholar?q=related:iOxrgJINZR8J:scholar.google.com/\&scioq=Милославова+И.А.+ Понятие+ ${ }^{+}+$структура + социальной + адаптации \&hl=en\&as_sdt $=0,5$ 
12. Pekhota, O., Stareva, A. (2006), "Personality-oriented learning: teacher training" Nikolaev: Ilion, 272. Retrieved from https://scholar.google.com/scholar?q=related:qaIfG_ydDsJ:scholar.google.com/\&scioq=Пехота+O.+M.+ +Особистісно++орієнтоване++навчання:++підготовка++вчителя\&hl=en\&as_sdt=0,5

13. Pihida, V. (2012), "Forms and methods of social and pedagogical support of children of labor migrants in the system of interaction of social services and educational institutions". Bulletin of Luhansk National University. Pedagogical sciences, 16, 129-137. Retrieved from https://scholar.google.com/scholar?q=related:2oonaj9ChvUJ:scholar.google.com/\&scioq=Булавенко+С.+ Д.++Шляхи++формування++соціально-

адаптованої++особистості++в++загальноосвітній + школі $+\& \mathrm{hl}=\mathrm{en} \& \mathrm{as} \_\mathrm{sdt}=0,5$

14. Semenyuk, L. (1996), Reader on developmental psychology: a textbook for students (2d ed.). Moscow: Institute of Practical Psychology, 219c. Retrieved from https://scholar.google.com/scholar?q=related:Fcjn6ZNWwyMJ:scholar.google.com/\&scioq=Семенюк+Л. M.+Хрестоматия+по+возрастной+психологии:+учебное+пособие+для+студентов \&hl=en\&as_sdt=0,5

15. Levchenko, K., Trubavina, I., Panok, V. (2015), "Socio-pedagogical and psychological assistance to families with children during the military conflict". Scientific methodological manual. Kiev. 174. Retrieved from https://scholar.google.com/scholar?q=related:BacWqO7GZHgJ:scholar.google.com/\&scioq=+Соціальнопедагогічна++та++психологічна++допомога++сім'ям++3++дітьми ++в++період++військового+конфлікту $+\& h l=e n \& a s \_s d t=0,5$

16. Tarasyuk, I. (2013), "Psychological features of speech adaptation of migrant children to a foreign language environment". $\quad$ Lutsk. $228 . \quad$ Retrieved from https://scholar.google.com/scholar?q=related:S9fRXg9Rx2IJ:scholar.google.com/\&scioq=Tарасюк+I.+B.+ Психологічні+особли+вості+мовленнєвої+адаптації+дітей+мігрантів+до+іншомовного+середовища\&hl=en\&as_sdt=0,5

17. Elkonin, D. (1971), "On the problem of periodization of mental development in childhood". Psychology issues, 4, 6. Retrieved from https://scholar.google.com/scholar?q=related:LHF0hBlbog4J:scholar.google.com/\&scioq=Эль конин+Д.Б. + К+проблеме+периодизации +психического+развития+в+детском+возрасте\&hl=en\&as_sdt=0,5 